\title{
Relocating Colonial Women in Resistance: An Interpretation of Rabindranath Tagore's Nastanirh and Chaturanga
}

\author{
T. K. Krishnapriya ${ }^{1}$, Dr Padma Rani², Dr Bashabi Fraser ${ }^{3}$ \\ ${ }^{1}$ Junior Research Fellow (UGC), Manipal Institute of Communication, Manipal Academy of Higher \\ Education, Manipal, India; Email: krishnapriya.t1@learner.manipal.edu; \\ ORCID ID: https://orcid.org/0000-0002-5795-1275 \\ ${ }^{2}$ Director \& Professor, Manipal Institute of Communication, Manipal Academy of Higher \\ Education, Manipal, India; Email: padma.rani@manipal.edu \\ ${ }^{3}$ Professor Emerita of English and Creative Writing, Director, Scottish Centre of Tagore Studies \\ (ScoTs), School of Arts \& Creative Industries, Edinburgh Napier University, Edinburgh; Email: \\ bashabifraserwriter@gmail.com
}

\begin{abstract}
The Colonial Bengal of the nineteenth and twentieth centuries was a place of contradictions. For instance, despite certain evident advancements in the resolution of the women's question, some of the emancipatory attempts of the period marked a rather dubious account of women's liberation as patriarchal underpinnings hegemonized the efforts. Amid this complex backdrop, the colonial women's position is further jeopardized by the western feminist scholarship that contrives colonial third world women as perennial victims and beneficiaries of emancipatory actions from the West. The paper attempts to relocate the colonial women and their resistance by negotiating the fissures in their construction. This study, informed by bell hooks' (1990) postulations on margin and resistance, simultaneously seeks to form a bridge between the experiences of marginalized women beyond borders. Rabindranath Tagore's Nastanirh (1901) and Chaturanga (1916) are chosen for close textual reading to examine the experiences of colonial women. The author's women protagonists often embody the social dilemma of the period. Tagore's Damini and Charu exist in the margin of resistance whilst Nanibala occupies the margin of deprivation. Significantly, Charu and Damini traverse the precarious "profound edges" of the margin to imagine a "new world" free of subjugation. Thus, the resistance offered by these women subverts the predominant conceptions of victimhood of colonial women, and it enables them to be posited as active agents.
\end{abstract}

Keywords: Tagore, hooks, Colonial Bengal, Resistance, Agency

\section{Introduction}

Rabindranath Tagore's Nastanirh (1901) and Chaturanga (1916) unravel in the complexities of their women - Charu and Damini. Even as Charu's and Damini's womanhood condemn them to the social margin, they harbor unbridled passion that prods and propels the world around them. Tagore has shaped the women of his literature with profound care and sentiments (Chatterjee, 
2015). As a result, they often breach and disrupt the bogus moral codes of colonial Bengal. Tagore's Binodini, a widow, unapologetically pursues her passion; Ela, a revolutionary, sacrifices herself at the altar of the Nation; Kumudini, a married woman, rejects the bond of holy matrimony. The paths chosen by these women transcend time as they embody shades of socio-cultural distress that remain relevant to date.

Further, Tagore's women are deeply anchored in the undercurrents of his time. Thus, it is imperative to address the dynamic socio-cultural background of the texts before we delve further to relocate Tagore's colonial women in the context of resistance. In this process of socio-cultural mapping, we intend to trace the significant temperaments of the period while actively attempting to negotiate the fissures in the voices of women.

The colonial Bengal of the nineteenth and twentieth centuries was a socio-cultural bedlam. The turbulent period witnessed the steady integration of the women's question into larger structural reformations. At large, nineteenth-century reformists and radical organizations like the Young Bengal Movement addressed female education, widow remarriage, polygamy, child marriage, and Satidaho (Sen, 1946, Tagore, 1973, Zafar, 2014). As a consequence, the British laid down the legal framework for the Abolition of Sati Act ( 1829), Hindu Widow remarriage Act (1856), and Child Marriage Restraint Act (1929), heralding a newly 'reformed' social set-up (Minturn \& Kapoor, 1995, Zafar, 2014).

Paradoxically, the women's voices were conveniently absent from the aforementioned narrative of their emancipation. For instance, Spivak (1985) points at an absolute absence of women's voices and their agency in the discussion of Satidaho. Hence, she traces its history between the extremes of orthodoxy's emotional appeal of "the women actually wanted to die" and the western rational appeal that spun the narrative of "white men saving brown women from brown men" (p.93). These absent voices were a collective outcome of the violent imperialism and the patriarchal Hindu society that denied women their rightful place. Moreover, the plight was aggravated by the monolithic and myopic construction of women as victims. The colonial officials constructed the satis as the perpetually subjugated victims. The mental state of the widows remained unexplored whilst their attempts at resistance were shunned. This reckoning ensured that the account of Satidaho stood fixated on Hindu men's patriarchal and religious domination as propagated by the British. Thus, even in their victimhood, the colonial women remained in the periphery of their tragic narrative (Mani, 1987).

Further, to a large extent, patriarchal agendas undermined the question of female education, which was considered integral to the progress of society. For example, Bhadralok used education as a tool to wean off their women from the lecherous popular culture of the lower class that the men found repugnant. (Banerjee, 1989). Sarkar (1997) says that while "striswadhinata" emerged as a critical disposition in colonial Bengal, emancipation was controlled and contained under the men's prerogative. The men liberated the women, and hence, it was "sometimes accompanied by refurbished patriarchy" (Sarkar, 1997, p.229). The overall impact of the "controlled emancipation" of women under the "male initiative" effectively silenced women as it denied them a participatory space in the center - the pivot- of the society (Sarkar, 1997, p.229). Hence, as we attempt to understand the resistance and agency of colonial women 
in these convoluted circumstances, it is crucial to explore the margins - the location of the suppressed womanhood.

Significantly, this study aims to locate the women and their resistance in the margins to advance them as active agents, although, historically, they were positioned as passive recipients of emancipatory actions. Before we delve further into the exploration, the framework of the study needs adequate engagement. An investigation of resistance or agency of colonial women under the eyes of the western feminist scholarship is improbable as it constructs third-world women as its mere beneficiaries. This paradigm rejects the agency of third-world women by reducing them to a homogenous entity and blatantly disregarding the context of their activism (Mohanty, 2003). Wilson (2008) points at the inefficiency of such an assumption as she says the connotations of victimhood and oppression should not be equated as it invalidates the struggle of the women who legitimately resist their oppression.

This study explores the resistance posed by the colonial women bearing in mind that these women may not have necessarily existed in the center of emancipation. Hence, the study is informed by bell hooks' (1990) postulations on the location of resistance. In her seminal work, Yearning Race, Gender, and Cultural Politics (1990), bell hooks breaches the narrative of margins as the site of unyielding deprivation to posit that margins and marginality can be grounds for substantial resistance. Moreover, she speaks of the home in the margins that persevere resistance. Following hook's postulations, this study examines the women of Nastanirh (1901) and Chaturanga (1916) in these margins of multiplicities. Further, we explore the margin as hooks' space of radicle openness while negating the limitations of the predominant connotations of resistance (hooks, 1990). While drawing implicitly from the socio-cultural settings of colonial Bengal, a close textual reading of the selected texts will be performed to understand the nuances of the resistance offered by its women and to align hooks' concepts to form a bridge between experiences of women beyond borders.

\section{The Home in the Margins: Charu and Her World}

The home is an essential entity in the world of Nastanirh. Its characters -Charubala, Bhupati, and Amal are all part of the home - albeit in differing capabilities. For the men of the novella, a home is a place where they enter and exit freely. However, for Charu, the woman, home is her world. For her, home is the location of her physical and intellectual growth. Charu blooms into a young woman from a shy child bride within the confinement of the home. She gawks at the center, the public space, from the window of her inner chamber. It is in the nothingness of the mundane home that she spends her "endeavourless, endless, days and nights" (p.4) as many other Bhadramahila of colonial Bengal.

Charu's conjugal tragedy arises from her husband's refusal to meet her wholeheartedly at the altar of the home as the outer world occupies him. The public space values Bhupathi for his skills and his wealth. Hence, he struggles to belong to Charu's space. He is "a man of the world" (p.21). Bhupathi's "world" is filled with deep discussions of government sanctions, accounts of his work and the occasional praises of his friends. More importantly, Charu hesitates to occupy this world as her presence in its arena is futile: 
"Charu entered the room once and, seeing Umapati, went out. She came back again after walking for a while outside and saw that both were engaged in an argument about accounts." (p.19)

The marital incompatibility of Bhupati and Charu emerges from the dissonance of their hearts. Bhupati, lost in the outside world, misses the "cracks" that have begun in "the arches and beams of the inner rooms" (p.66). Consequently, Charu lives in the margins of her home and the marginality of her matrimony.

According to bell hooks (1990), the life in the margins makes her "different" and allows her to "see things differently" (p.152). The dominant class- the centre's occupants- must enter this space to thoroughly comprehend the margin and its occupants as they are not the same as Them. For Charu, her husband fails to understand her existence in the margins of the home. Even though Bhupati physically enters the home, he does not fully enter the site of Charu's deprivation. This impedes his vision of Charu and how she sees the world. Such a misapprehension pushes Bhupati to bring a female companion - Manda- to cure Charu's loneliness. Once, as he refuses to comprehend her wholly, he asks, "See the way I understand you, but for that do I have to read Meghnad Badh or Kabikankan Chandifrom beginning to end?" (p. 21)

As Bhupati and Charu fail to synthesize their worlds, Charu suffocates in the inner rooms of their home. Yet, she remains bound as matrimony has tricked and tied her existence to margins. Hence, the margin for Charu is a space of longing and loneliness. It is at this space that Amal, Bhupati's cousin, meets her. He meets Charu at her space in the margin - wholly and honestly. Thus, Amal, a man, enters the site of domination to comprehend Charu fully. Therefore, they exist and thrive in the space. Even as Amal moves in and out of the margin, he returns to her space in the margin. It is in the gardens of her home in the margin that they indulge in poetry. It is in the inner rooms of the home that their relationship blooms through Amal's juvenile demands. It is in the margin that they laugh and dream together.

Further, the margin transforms to a site of resistance as Charu begins her transgression. Charu begins her resistance against the bondage of patriarchal domination as she, a married woman, falls for Amal. This gradually corrodes the marginality conferred on her by the chains of holy matrimony. Consequently, Charu's home in the margins becomes the site of a "production of counter-hegemonic discourse" (hooks, 1990, p.149). Moreover, as her marginality takes on the characteristics of resistance, it also engages a scope for radical openness. Charu's feelings for Amal arise from the radical possibility offered by the margin. This enables her to resist the loneliness of her inferior existence predestined by patriarchy. The radical possibility enables Charu to loosen her conjugal ties to pursue Amal.

Besides, as Amal slowly moves away, she "clings" to her - and their - existence in the margin as she pushes him to start a magazine with her (hooks, 1990, p 150). However, the magazine has only "two editors, two writers, and two readers" (p.37) and "its door was closed even to the outside world" (p.38). Here, the magazine stands in as an extension of Charu's resistance in the margins and her desperate bid to hold on to her rebellion. However, this alternative, "new world" arising from the radical possibility pushes her to the "profound edge" of the margin (hooks, 1990, p.149). This edge, according to hooks, is risky. As his brethren betray Bhupati and Amal marries a rich man's daughter to help Bhupati, Charu finds herself at the precarious margin, and 
as Amal leaves for England, her home in the margin crumbles. Nevertheless, Amal's departure strengthens Charu's resistance. She further clings to her resistance as she adamantly refuses to indulge her husband in her company. As Bhupati tries to breach Charu's home in the margin, she builds a "secret temple of sorrow" in her mental space.

"In this way, Charu, beneath the landscape of all her household work, all her duties, dug an underground tunnel. In that lightless, motionless darkness, she built a secret temple of sorrow, decorated only with a garland of her tears. There, her husband, the rest of the world, had no right to enter. If that place was secret, it was also profound, also most beloved." (p. 76)

In this secret space, she dwells away from the disguise of the outer world. It also becomes the ground for her worship of Amal as she cherishes their memories in its fortitude. Consequently, her second and crucial resistance against patriarchy unfolds in the depth of this particular space as she shuts its door to her husband and all of the world. She finds solitude in its corners even as she wears the cloak of a wife in her husband's presence. Perhaps, it is this space of resistance, free of its patriarchal underpinnings that she chooses to inhabit as she refuses to move with her husband to Mysore. Her resistance against the bondage of patriarchy and her lonely marriage continues despite Amal's absence. Thus, Charu's resistance culminates in the assertion of her agency as she willingly occupies the home free of the two men in her life.

\section{Marginality and Womanhood: Damini's Resistance and Nanibala's Silence}

Chaturanga operates and thrives in its various oppositions -theism vs atheism, traditionalism vs modernism, spiritualism vs materialism, and spiritualism vs rationalism. Amid this oppositions, Tagore expertly constructs two prototypes of women - Nanibala, who "accepted the stain of impurity on herself", and Damini, who "enjoys life to the hilt" (p.39).

We begin our exploration with Damini as she occupies the core of Chaturanga whilst bound to the social margin of widowhood. Her social status grants her no privilege, and it further exacerbates the predicaments of her womanhood as widowhood condemns her to a life of servitude chosen by her husband before his untimely death. Sibatosh, her husband, bequeaths Damini and all their property to his spiritual Guru Leelananda Swami. Damini's marginality, arising from her widowhood and nonconformity, ruthlessly invalidates her being. According to Uma Chakravarti, "Once a woman ceases to be wife (especially a childless wife) she ceases to be a 'person' - she is neither daughter nor daughter-in-law" (1995, p.1).

Though nineteenth-century Bengal outlawed the practice of Satidaho, widowhood remained (and remains) a weapon of subjugation. For an upper-caste woman, the husband's demise was identical to one's social death (Chakravarti, 1995). Damini resists this fate of demise forced upon her social being. In the process, she situates her marginality as "the central location of resistance", as posited by hooks (1990, p.149). For her, resistance was her way forward as she refuses to succumb to social expectations. She refuses the spiritual guidance of the Guru -her guardian- through constant defiance. She laments at her fate of subjugation: 
"You devotees have put a chain around the feet of this woman without faith and put her in your prison of devotion. Have you left any other way open for me?" (p.56)

She resists the Guru's influences by chasing her materialistic desires. She refuses to dress and behave like a widow. Her widowhood, thus, becomes the site of her resistance as the injustices of her fate mount. She creates "a cyclone among his disciples and their steady stream of spiritual life" (p.55). Her resistance "scares" the Guru and his disciples alike as the site of her revolt is located in the margin, a domain of patriarchal domination, which generally stands for deprivation and subjugation (p.55). Moreover, Damini, a widow, subverts the patriarchy that controls her sexuality and indulgences as she pursues Sachis and marries Sribilas. Patriarchy configures enforced widowhood as a means to control female sexuality (Chakravarti, 1995). Damini resists the attempt by tearing apart the code of abstinence from her location in the margins as a wretched widow. Her marginality, therefore, consolidates to a site of "production of a counter-hegemonic discourse" against the patriarchal domination imposed on her (hooks, 1990, p.149).

Further, bell hooks posit that once the margin and marginality assimilate the spirit of resistance, it is not "just found inwards" but permeates the very "habits and of being and the way one lives". In this perspective, Damini's everyday life is a revolt as she topples the codes of widowhood by refusing to adhere to its stringent conduct. She laughs "full-throated" and "aroma of spices arises" from her kitchen. She dresses as she pleases and roams freely (p.39). She nurtures a ferocious mongoose, an ugly street dog, and a kite, much to the annoyance of her Guru.

Her marginality essentially aids in her imagination of "alternatives, new worlds" posited by hooks, overturning the prevailing paradigms (1990, p.150). This new world comes to fruition as she marries Sribilas and finds a spiritual Guru in Sachis. Her marginality also provides her with a chance at "radical openness" as widowhood interrupts the grip of male authority in her life. For hooks,

" ...this space of radical openness is a margin-a profound edge. Locating oneself there is difficult yet necessary. It is not a "safe" place." (hooks, 1990, p.149)

Damini precariously pursues her passion at this "profound edge". It is at the altar of "radical possibility" that she approaches Sribilas and openly dotes on him as she wishes to irk Sachis and the Guru (hooks, 1990, p.149). More importantly, it is at the juncture of a radical possibility that Damini approaches a sleeping Sachis in the cave. Furthermore, the radical possibilities of the "profound edge" enable her imaginative alternative "new world" to become a reality as she marries Sribilas. (p.150)

Nevertheless, the risks of the radical actions threaten her existence as the men decide to relocate her to an aunt's house "for the convenience of their sadhana" (p.60). Damini "clings" to her marginality to launch a rebellion against the structures that attempts to bend and chain her. According to hooks (1990), marginality can be "a site one stays in, clings to even, because it nourishes one's capacity to resist" (p.150). Initially, as a moment of vulnerability possess her as the Guru slowly corrodes her resistance, she wishes to die. It is at the moment of loss of her resistance that she wishes to perish. Further, it is the margins she seeks out as the men around her decide her fate. Her marginality is her weapon of choice for her resistance, and hence, she grasps on to the risky edge in the margin as she protests, 
"What I have been told is that I have no mother, no father, no brother; I have no home, no money, nothing. This is why I am a heavy burden. You have taken that burden at your own will. Now you cannot unburden it on somebody else's shoulder." (P. 59)

Moreover, as Damini involves herself in the sect's spiritual activities upon Sachis's request, her marginality slowly begins its transformation to a site of oppression as she surrenders her public resistance in a bid to win his approval. Nevertheless, she clings to her resistance - the site of her transgression- and refutes victimhood in secrecy. Even as she chants, "I would not transgress, I should not transgress", she looks for Sachis (p. 63). Thus, Damini's true essence lies in her resistance.

Contrary to Damini, Nanibala of Chaturanga exists in the repressive margin. Growing up as a widow's daughter, she holds no rights. As a teenager, she falls prey to Sachis' elder brother's philandering ways and ends up pregnant. Sachis rescues Nanibala and finds her a shelter in his uncle's home - an action highly scandalous for their period. Her existence wobbles the foundations of the orthodox society as she is a "slut" in their eyes (p.25, p.28).

However, Nanibala offers no resistance against her deprived fate. She silently accepts her life. Rather interestingly, she conveys her emotions through her actions and does not utter a word until the very end chapter of her life. For hooks (1990), "silences" are the "unaddressed places" within the overall growth of a person (p.146). It is this "silence" that breaks the voices of the oppressed, and significantly, the "silences" are an instrument of oppression. Nanibala personifies this silence. Her social status silences her as patriarchy restrains her to the deprived margin. Nanibala also exemplifies Spivak's (1985) subaltern who cannot speak. As Nanibala finally speaks, she simply seeks Jagmohan, her protector's, blessings. Even then, her voice remains broken and full of pain - it is the "speech of the suffering" (p.146). hooks briefly addresses the broken voice as she says,

"When you hear the broken voice you also hear the pain contained within that brokenness - a speech of suffering; often it's that sound nobody wants to hear." (hooks, 1990, p. 146)

Perhaps, it is essential at this point to look at Tagore's construction of Damini's voice, which is fundamentally the voice of resistance in Chaturanga. Damini has no qualms about making her opinion known. She refutes without hesitation as she calmly resists any unfavorable demands. Hence, her unwavering voice loudly protests and supplements her resistance at the margin.

Nanibala's end befalls as Sachis decides to marry her in order to save her from further disgrace. At this juncture, Nanibala performs a final act born out of her will; she commits suicide. Circumstances of her exertion of free will are dubious as she signs her suicide note as "Nanibala, the sinner" (p.30). Thus, her suicide note negates the possible chances of her resistance as she remains a sinner in her eyes. Thus, Nanibala's existence in the margin demonstrates it as a space of deprivation. To further understand and differentiate the margins occupied by Damnini and Nanibala, it is essential to look at hooks' distinction between "the marginality imposed by oppressive structures" and "the marginality one chooses as a site of resistance" (1990, p.153). Nanibala can be located in the former as the patriarchal stronghold subjugates her. Her marginality is imposed by patriarchy which views her as an immoral woman - "a slut" (p.25, p.28). 
She perishes from the trauma of her deprivation and repression. Damini can be located in the latter margin; for her, marginality is a site of resistance with radical possibilities. Thus, Chaturanga's dual archetypes of women signify contrasting manifestations of resistance.

\section{Conclusion: Resistance and Colonial Women}

The margins of Charu, Damini and Nanibala existences appear to be a space of contradictions. It deprives its occupants, yet at times, launches rebellions. For the colonial women of Chaturanga and Nastanirh, their marginality arises from their womanhood and its attached social expectations. Damnini, Nanibala, and Charu defy these expectations in various ways and are subsequently placed on the edges of the social margin. Damini, the widow, refutes the codes of widowhood whilst Charu overpowers the codes of Hindu marriage. Both these women unleash revolts against the oppressive structures of patriarchy, which blatantly dictates the conduct of womanhood. As a result, Damini and Charu construct their marginality as a site of resistance. For them, the margins signify the ability to perceive and build alternate worlds as they resist the oppressive structures within their ambit. As for Nanibala, she occupies the margin as she is the fallen, immoral woman. Unlike Damini and Charu, she remains silenced throughout the novella. Although all three exist on the brink of society, for Nanibala, the margin represents repression and patriarchal domination. Nanibala occupies the margin patriarchy has constructed for her, and therefore, she finds no respite within its borders. Hence, Tagore's women protagonists embody the contradictions of the margin.

A re-reading of Nastanirh and Chaturanga in the light of bell hooks' postulations acknowledges the differences and similarities in the conception of resistance among marginalized women beyond borders. In colonial Bengal, women were pushed to the margins because they were simply 'women'. Nanibala - the poor unmarried mother, Damini -the once rich widow, and Charu - the rich housewife, occupy the margins despite their differing social standings. Hence, it is the gender divide that mainly aids in the process of marginalization of these women. As for bell hooks, her marginality arises from the systematic annihilation and oppression of her race and racial identity. Nonetheless, the margins offer endless radical opportunities to the women Damni, Charu, and hooks- as it becomes the domain of their resistance.

However, a significant departure from hooks' postulations is marked by the inability of colonial women to move to the center. For hooks and her people, their existences in the margins do not interfere with their ability to move to the center. They work at the center, and further, their work was integral to the center's operation. More importantly, the margin was a place hooks chose to inhabit even as she explored the center. On the other hand, colonial Indian women could not easily transgress to the center from the margins. Damini, Charu, and Nanibala are shaped within the precincts of the home. The men Bhupati, Amal, Sribilas, and Sachis freely occupy the center. For instance, at the center, Bhupati sets up his newspaper, and it is at the center that Sribilas and Sachis bravely attempt a social reformation. The center in the colonial Indian context transforms into a public space /world where power is concentrated away from the women. The men occupy the powerful center while women occupy the home. Furthermore, the center was also overridden by colonialism. Women's limited entry to the center can be perceived as a combined impact of colonialism and the inherent patriarchy of the Indian society, which restrained women "doubly" in the "shadow" of its men (Spivak's, 1985, p.84). For hooks, her home in the margins is devoid of 
patriarchal underpinnings when it transforms to a site of resistance. However, for colonial Indian women, the center was out of their grasp as it was overridden by colonialism, and the home embodies the margins and trembles under its innate patriarchy.

Thus, the resistance of the colonial Indian women may not have necessarily stemmed from their journey to the center or their awareness of the center. Such a paradigm may not necessarily resonate with the dominant footings of agency or resistance as these women may appear ignorant and backward under the western eyes (Mohanty,2003). However, it would be misgiving to subvert the resistance offered by colonial women despite their struggle against the twofold domination. For Charu and Damini, their resistance begins from their absolute deprivation. Moreover, their marginality propels their resistance. Hence, as the margin transforms to a site of resistance, the actions of these women demonstrate glimpses of active agency. Even as women's voices remain relatively absent from the decision-making center of colonial Bengal, the likes of Damini and Charu exert their agency within the margins and resist in a bid to conceive a new world.

\section{Funding Disclosure/Acknowledgement}

No funding has been received for this research/publication.

\section{References}

Banerjee, S. (1989). Marginalization of Women's Popular Culture in Nineteenth Century Bengal. In Sangari, K., \& Vaid, S. (Eds.), Recasting women: Essays in Indian colonial history. (pp. 127-179). Rutgers University Press.

Chakravarti, U. (1995). Gender, caste and labour: Ideological and material structure of widowhood. Economic and Political Weekly, 36 (30), 2248-2256.

Chatterjee, M. (2015). The Delineation of the Female Subject in Rabindranath Tagore's Novel Farewell, My Friend. In Banerji, D. (Ed.), Rabindranath Tagore in the 21st century. (pp. 145-156). Springer.

Hooks, B. (1990). Yearning: Race, Gender, and Cultural Politics. South End Press.

Minturn, L., \& Kapoor, S. (1993). Sita's daughters: Coming out of purdah: The Rajput women of Khalapur revisited. Oxford University Press.

Mohanty, C. T. (2003). Feminism without borders. Duke University Press.

Sarkar, S. (1997). Writing social history. Oxford University Press.

Sen, A. (1946). Notes on the Bengal renaissance. Peoples publishing House

Spivak, G. (1985). Can the Subaltern Speak. In Williams, P., \& Chrisman, L. (Eds.). (2013). Colonial discourse and post-colonial theory: A reader. (pp.66-111). Routledge.

Tagore, R (2019). Quartet Chaturanga (N.K Battacharjee Trans). Niyogi Books. (Original work published 1916)

Tagore, R. (2009). Broken Nest and Others (S. Mohanty, Trans.). Tranquebar Press. (Original work published 1901) 
Tagore, S. (1973). Raja Rammohun Roy. Ministry of Information and broadcasting Government of India.

Wilson, K. (2008). Reclaiming 'agency', reasserting resistance. IDS Bulletin, 39(6), 83-91.

Zafar, M. (2014). Social Reform in Colonial Bengal: Revisiting Vidyasagar. Philosophy and Progress, 55(1-2), 109-124.

Ms. T. K. Krishnapriya is Junior Research Fellow (UGC) pursuing her Doctoral Studies at Manipal Institution of Communication, Manipal Academy of Higher Education, Manipal, India. Her areas of interest include Tagore studies and Gender Studies.

Dr Padma Rani is Director \& Professor at Manipal Institution of Communication, Manipal Academy of Higher Education. Her areas of research include ICTs, Gender, Media Effects, Human Rights, Alternative Media. She has published in reputed journals and presented her research at prestigious national and international conferences.

Dr Bashabi Fraser, CBE, is Professor Emerita of English and Creative Writing, Director, Scottish Centre of Tagore Studies (ScoTs), School of Arts \& Creative Industries, Edinburgh Napier University. Her recent publications include Rabindranath Tagore, a critical biography (London: Reaktion Books, Critical Lives Series, 2019), The Ramayana, A Stage Play and a Screen Play (Jaipur: Aadi Publishers, 2019) and My Mum's Sari, illustrated by Zoe Barnish (London: BBC Word Wave Bitesize Series, 2019) 